Władysław T. Miodunka

Uniwersytet Jagielloński, Kraków

w.miodunka@uj.edu.pl

\title{
ZNACZENIE PRAC ROMANA LASKOWSKIEGO DLA BADAŃ AKWIZYCJI JĘZYKA POLSKIEGO POZA GRANICAMI KRAJU ORAZ DWUJĘZYCZNOŚCI POLSKO-OBCEJ
}

Słowa klucze: akwizycja języka etnicznego, język polski poza Polską, bilingwizm, bilingwizm polsko-szwedzki, Polacy w Szwecji

Keywords: acquisition of an ethnic language, the Polish language outside of Poland, Polish-Swedish bilingualism, Poles in Sweden

Zainteresowanie Romana Laskowskiego badaniem przyswajania języka polskiego przez dwujęzyczne dzieci polskie wychowywane w Szwecji należy wiązać z końcem lat 8o. wieku XX, konkretnie z rokiem 1989, kiedy wraz z grupą współpracowników z Uniwersytetu w Göteborgu rozpoczął szeroko zakrojone badania w ramach programu POLSVE. W książce Język w zagrożeniu. Przyswajanie języka polskiego $w$ warunkach polsko-szwedzkiego bilingwizmu autor pisze, że

[...] celem tych badań było określenie socjolingwistycznych uwarunkowań przyswajania i posługiwania się językiem polskim przez dzieci polskich imigrantów w Szwecji, zasadniczym jednak zadaniem, jakie postawione zostało w projekcie, było zbadanie mechanizmów przyswajania przez dzieci języka polskiego w warunkach bilingwizmu (Laskowski 2009: 33).

Biorąc pod uwagę cele badawcze tak ustalone przez kierownika projektu, rezultaty tych badań postaram się pokazać na tle badań przyswajania polszczyzny poza granicami kraju oraz badań bilingwizmu polsko-obcego. Jeśli chodzi o ten pierwszy zakres, to już na wstępie trzeba wyraźnie powiedzieć, że studia Laskowskiego są 
badaniami pionierskimi, ponieważ nikt wcześniej nie interesował się tematem przyswajania polszczyzny przez dzieci polskie w warunkach bilingwizmu. Uwzględniając fakt, że także po opublikowaniu monografii Język $w$ zagrożeniu nie podjęto badań lingwistycznych w tym zakresie, trzeba stwierdzić, że jego prace pozostają do chwili obecnej jedynymi w literaturze polskiej, dzięki czemu nabierają specjalnego znaczenia.

Owszem, od lat 70. poprzedniego wieku prowadzono badania nad polskimi grupami etnicznymi i mniejszościami narodowymi w różnych krajach świata, zwane wówczas badaniami polonijnymi, a w ich zakres wchodziło również opisywanie języka polskiego poza granicami kraju (por. Dubisz 1997b: 13-18; Miodunka 2003: 72-85; Sękowska 2010: 69-94), jednak wśród poruszanych tematów nie znajdujemy przyswajania polszczyzny przez polskie dzieci żyjące poza granicami kraju. Podsumowanie badań nad zbiorowościami polonijnymi w Europie stanowi tom Polonia $w$ Europie (Szydłowska-Cegłowska 1992a), w którym o mechanizmach przemian języka polskiego na emigracji pisze redaktorka tomu, natomiast historię i kształtowanie się Polonii w krajach skandynawskich, w tym również w Szwecji, przedstawia Elżbieta Later-Chodyłowa (1992). Syntezę wiedzy na temat zachowania i używania polszczyzny poza Polską przynosi książka pod redakcją Stanisława Dubisza (1997a). W tomie tym zawarto między innymi próbę charakterystyki kontrastowej polszczyzny poza naszym krajem (Dubisz 1997c), a także ogólny opis polszczyzny używanej w Szwecji Elżbiety Sękowskiej, która uwzględniła także dotychczasowe rezultaty badań Laskowskiego w tym zakresie (Sękowska 1997). Co ciekawe, sam Laskowski nie odwoływał się do tych prac, choć zapewne znał je. Wiedzę historyczną i socjologiczną o Polonii szwedzkiej czerpał z prac Nilsa Uggli (np. Uggla 1991), znającego tę zbiorowość $\mathrm{z}$ autopsji. Swoje badania uczony postrzegał w kontekście światowych, szczególnie zaś europejskich studiów nad językami imigrantów, żyjących w różnych krajach osiedlenia, o czym świadczy literatura przywoływana w omawianej monografii i artykułach na ten temat. Przy okazji warto dodać, że początki jego zainteresowań polszczyzną poza granicami kraju sięgają początków lat 80. minionego wieku i wiążą się z pracą o logice zmian językowych na przykładzie polszczyzny w Kazachstanie (Laskowski 1984: 23-31).

Na początku lat 90. XX w., kiedy zaczęły się ukazywać prace Laskowskiego na temat polszczyzny dwujęzycznych dzieci polskich w Szwecji (np. Laskowski 1991), istniała już co prawda monografia Bronisławy Ligary (1987), ale była to praca z zakresu historii języka polskiego, stanowiąca równocześnie studium przypadku bilingwizmu polsko-francuskiego jednostki tak znaczącej w literaturze polskiej jak Zygmunt Krasiński. Jednak na rozwój badań bilingwizmu polsko-obcego trzeba było czekać aż do roku 200o, kiedy w różnych ośrodkach akademickich w Polsce zaczęto na szerszą skalę prowadzić badania zjawiska bilingwizmu i publikować monografie, które doczekały się pierwszego podsumowania w artykule Władysława Miodunki: 
Ostatnie dziesięciolecie to okres wzmożonego zainteresowania dwujęzycznością. Wprawdzie omawiane prace funkcjonują jakby na marginesie zasadniczych zainteresowań polskiej lingwistyki, powinny się one jednak znaleźć w jej głównym nurcie, gdyż to właśnie one są najbliższe nowego paradygmatu w humanistyce, jakim stała się komunikacja międzykulturowa. Język odgrywa w komunikacji międzykulturowej w dalszym ciągu zasadniczą rolę, choć nacisk kładzie się nie na język jako system złożony z podsystemów, ale na język jako narzędzie budowania własnej tożsamości i walencji kulturowej, jako narzędzie tworzenia i odbioru kultury, jako podstawę każdej kultury (Miodunka 2010: 68).

W cytowanej pracy znalazło się krótkie omówienie monografii Laskowskiego (2009), która została zaliczona do grupy sześciu książek poświęconych analizie zjawiska bilingwizmu wśród dzieci i młodzieży w różnych krajach świata, podczas gdy samo zainteresowanie bilingwizmem dziecięcym zostało uznane za ważne dla przyszłych losów polszczyzny poza Polską. Mimo że publikacja monografii Laskowskiego przypadła na okres wzrastającego zainteresowania bilingwizmem, pozostała jednak pracą osobną ze względu na to, że jej zasadniczym celem była analiza procesu przyswajania polszczyzny przez dwujęzyczne dzieci polskie w Szwecji, zjawiska w zasadzie pomijanego lub traktowanego marginesowo w innych książkach na temat bilingwizmu. Inną przyczyną uznania książki Laskowskiego za klasę dla siebie, było to, że znaczna jej część została poświęcona przyswajaniu kategorii przypadka przez dzieci, a więc zjawiska centralnego w strukturze fleksyjnego języka polskiego, niezwykle ważnego dla całościowej znajomości polszczyzny przez dzieci polonijne.

Na tej podstawie można stwierdzić, że Laskowskiego jako lingwistę interesował nie tyle opis polszczyzny dzieci polskich w Szwecji, ile analiza ogólnego zagadnienia, jakim było i jest przyswajanie polszczyzny przez dwujęzyczne dzieci poza granicami kraju. Mając jasno wytyczony cel, uczony koncentrował się na jego osiągnięciu, inne tematy traktując jako pomocnicze, bo stanowiące tło zagadnienia głównego. Bardzo precyzyjnie zostało to wyrażone w podtytule omawianej monografii, w którym tematem głównym jest „przyswajanie języka polskiego”, pomocniczym zaś, ale stanowiącym o specyfice prowadzonych badań - „warunki polsko-szwedzkiego bilingwizmu".

Dwujęzycznym dzieciom polskim w Szwecji, ich polszczyźnie oraz procesowi jej przyswajania Laskowski poświęcił kilkanaście artykułów, opublikowanych po polsku i po angielsku, podsumowanie badań zawarł natomiast we wspomnianej już monografii. Składa się ona z trzech części. Część pierwsza pracy, zatytułowana Dzieci polskie w Szwecji, przynosi charakterystykę socjolingwistyczną badanej grupy 133 dzieci w wieku 5-15 lat, których co najmniej jedno z rodziców pochodziło z Polski. Dzieci były urodzone w Polsce lub w Szwecji, w tym pierwszym zaś przypadku mieszkały w Szwecji co najmniej pięć lat. Za istotną nowość należy uznać objęcie badaniami dzieci z rodzin mieszanych, gdyż tendencja do zawierania mieszanych małżeństw, dostrzeżona tu po raz pierwszy, wyraźnie nasiliła się w latach 
późniejszych, co widać na przykładzie polskiej migracji do Wielkiej Brytanii po 2004 r. Część druga: Język idiolektów polskich dzieci w Szwecji. Zarys problematy$k i$, stanowi ogólną charakterystykę polszczyzny dwujęzycznych dzieci polskich w zakresie fonologii, fleksji, składni i słownictwa. Część trzecia wreszcie, Kategoria przypadka, została poświęcona najpierw ogólnej analizie systemu przypadkowego w polskich idiolektach dzieci w Szwecji, potem zaś stopniowi przyswojenia poszczególnych przypadków.

Z tej ogólnej prezentacji treści monografii można odnieść wrażenie, że około 2/3 całości poświęconych jest ogólnemu opanowaniu polszczyzny oraz zakresowi przyswojenia przypadków, z czego mogłoby wynikać, że bilingwizm polsko-szwedzki badanych dzieci stanowi raczej odległe tło. Byłoby to jednak wrażenie mylne, ponieważ dokładny obraz tego zjawiska znajdujemy w części pierwszej pracy, chociaż w spisie treści nic tego nie zapowiada: autor nie użył ani terminu bilingwizm, ani też terminu język szwedzki. I tak np. w podrozdziale Wplyw rodziny i środowiska pozarodzinnego na zakres użycia języka polskiego uczony omówił dokładnie zakres użycia języków polskiego i szwedzkiego w zależności od rozmówcy, od wieku dziecka oraz języka ojczystego rodziców. Dowiadujemy się też z niego, że w części rodzin językiem porozumienia dziecka $z$ rodzicami jest szwedzki lub inny język, co znacznie ogranicza szanse dzieci z tych rodzin na przyswojenie sobie języka polskiego. Oczywiście, zdarza się w tej grupie zjawisko „swoistej wewnątrzrodzinnej dyglosji” (ibid.: 47) polegającej na tym, że polszczyzna jest narzędziem komunikacji z matką, podczas gdy język szwedzki służy porozumiewaniu się całej rodziny ze względu na to, że ojciec albo mówi po polsku zbyt słabo, albo też nie mówi wcale. $Z$ tabeli informującej o języku komunikacji badanych dzieci w zależności od ich rozmówców dowiadujemy się, że z matką po polsku rozmawia 50\% badanych, w obu językach $40 \%$, a wyłącznie po szwedzku 10\%. Jeśli rozmówcą dziecka jest ojciec, w rodzinach mieszanych rozmawia się z nim najczęściej po szwedzku (34,5\%), w rodzinach polskich - po polsku (34\%), po polsku i po szwedzku (25\%), a także w innym języku niż polski i szwedzki (6,5\%). W wyniku analiz Laskowski ustala hierarchię typów sytuacji językowych sprzyjających zachowaniu przez drugie pokolenie języka ojczystego ich rodziców:

\section{RODZICE $\rightarrow$ RODZEŃSTWO $\rightarrow$ KOLEŻEŃSKI KRĄG POZA SZKOŁĄ/PRZED- \\ SZKOLEM $\rightarrow$ KOLEDZY W SZKOLE/ PRZEDSZKOLU,}

w której kierunek strzałki wskazuje pogarszanie się warunków zachowania języka etnicznego (ibid.: 56).

Trzeba zwrócić uwagę na to, że Laskowski dokonał tu szczegółowych, drobiazgowych wręcz analiz, które pozwalają mu stwierdzić, że

[...] tylko (aż?) dziewięcioro dzieci z czysto polskich rodzin nie używa ojczystego języka matki nawet w rozmowie z nią. Można przypuszczać, że są to rodziny (matki), 
które wybrały strategię „ucieczki do przodu”, o której negatywnych skutkach dla rozwoju intelektualnego i społecznego dziecka była mowa [...] (ibid.: 48).

Strategia „ucieczki do przodu” polega na komunikowaniu się rodziców z dziećmi w języku szwedzkim, aby ułatwić im asymilację w nowym społeczeństwie i akulturację, nawet jeśli sami rodzice nie znają wystarczająco dobrze tego języka. Strategią przeciwstawną jest strategia „oblężonej twierdzy” przyjmowana przez rodziny pielęgnujące co prawda język i kulturę polską, ale odrzucające

[...] język i kulturę dominującego społeczeństwa jako obcych, wręcz wrogich, zdeprawowanych, godnych pogardy [...]. Prowadzi to do postępującej samoizolacji (i izolacji) takich środowisk imigracyjnych, odbiera im szansę zrozumienia otaczającego świata, utrwala poczucie społecznego wykluczenia, uniemożliwia stanie się pełnoprawnym członkiem społeczeństwa. Strategia ta owocuje często głębokim rozchwianiem osobowości dziecka, a jej skutkiem może być zespół zaburzeń psychicznych zwanych anomią (ibid.: 21-22).

W trakcie badań nie proszono dzieci o określenie stopnia znajomości polskiego i szwedzkiego w zakresie poszczególnych sprawności (rozumienia ze słuchu, rozumienia tekstów pisanych, redagowania tekstów pisanych i mówienia), pytano natomiast o względną łatwość posługiwania się każdym z tych języków. Jasne jest, że w przypadku takich pytań znajomość języka jest sprowadzana zazwyczaj do mówienia nim i rozumienia go ze słuchu, pomija się tu natomiast pozostałe dwie sprawności, których opanowanie jest zwykle (znacznie) gorsze od opanowania mówienia. Rezultaty badań dowodzą, że badane dzieci polskie cechuje bilingwizm z dominacją języka szwedzkiego, ponieważ 65,5\% badanych stwierdziło, że woli mówić po szwedzku niż po polsku. Tylko w przypadku 25,5\% dzieci można zakładać bilingwizm zrównoważony, gdyż badane dzieci tak samo łatwo mówią po polsku, jak po szwedzku. Grupa dzieci preferujących mówienie po polsku jest najmniejsza.

W części pierwszej swej monografii uczony dzieli się też wieloma obserwacjami szczegółowymi, z których dla przykładu przytoczę jedną:

Obserwowałem wiele polskich dzieci oddanych do przedszkola w Szwecji. Jednym z najbardziej dramatycznych był przypadek dwuletniego chłopczyka, dla którego pierwsze miesiące przedszkola okazały się wyjątkowo trudne. Przez parę miesięcy dziecku, nieznającemu zupełnie języka szwedzkiego, ledwie zaczynającemu mówić po polsku, towarzyszyła w przedszkolu babcia, również ani słowa nieznająca po szwedzku. Po jakimś czasie babcia zaczęła zostawiać w przedszkolu chłopczyka samego. Chłopczyk reagował zawsze w ten sam sposób - nieprzerwanym szlochem, potem wymiotami. Wystarczyło jednak, abym ja - człowiek zupełnie mu obcy odezwał się do niego po polsku, żeby się uspokoił, a nawet zaczął uśmiechać. Język rodziców przywracał jego zrujnowanemu, obcemu i groźnemu światu porządek, nadawał mu sens, dawał poczucie bezpieczeństwa (ibid.: 31; wyróżn. - W.M.). 
Socjologowie i socjolingwiści wiedzą, że proces adaptacji do nowej rzeczywistości językowej i kulturowej zaczyna się między innymi od szoku kulturowego, polegającego na poczuciu wyobcowania o różnym natężeniu i na negacji nowej rzeczywistości. W znanej mi literaturze na ten temat nie spotkałem jednak tak przejmującego opisu szoku językowego dziecka. Przytoczyłem go, aby zwrócić uwagę na wyczuwalne w monografii dwa stanowiska autora: dominujące stanowisko bezstronnego, obiektywnego badacza rzeczywistości społecznej i językowej, dążącego do rzetelnego jej opisu i analizy, oraz drugie, widoczne tylko w szczegółach, stanowisko człowieka głęboko zaangażowanego w opisywaną rzeczywistość, współodczuwającego wiele zdarzeń wraz z tymi, których bezpośrednio dotyczyły.

Poza tym przy okazji chciałem choć częściowo zakwestionować uwagę uczonego wyrażoną w przypisie na s. 11 o nieznajomości aparatu badawczego pozwalającego na socjologiczną analizę zbiorowości. W cytowanym fragmencie autor powołał się na obserwację uczestniczącą, metodę badawczą stosunkowo często wykorzystywaną w socjologii i antropologii kulturowej, pozwalającą badaczowi na bezpośrednie obserwacje, dzięki którym może on częściowo uniezależnić się od danych pozyskanych od badanych dzięki własnym doświadczeniom i opiniom na temat tej samej rzeczywistości.

We wstępie do badań stopnia opanowania polszczyzny przez dzieci polonijne, przedstawionych w części drugiej monografii, Laskowski czyni następujące zastrzeżenie:

Stopień biegłości w opanowaniu języka ojczystego reprezentowany przez poszczególnych użytkowników języka w diasporze podlega drastycznemu zróżnicowaniu, poczynając od prawie doskonałego opanowania języka wyniesionego z domu rodzicielskiego, a kończąc na pełnej jego utracie. Tak więc nawet jeśli ograniczylibyśmy się do badania języka jakiejś wybranej społeczności w diasporze [...], w rzeczywistości będziemy mieli do czynienia nie $z$ jednym systemem językowym reprezentowanym przez różne indywidualne idiolekty, lecz ze zbiorem idiolektów poszczególnych rozmówców, znacząco różniących się między sobą zarówno gramatycznie, jak i leksykalnie (ibid.: 85-86; wyróżn. - W.M.).

Podsumowując swe obserwacje stopnia opanowania polszczyzny przez dzieci polonijne ze Szwecji, autor zauważa jednak, że analiza idiolektów

[...] daje wartościowy obraz zarówno czynników sprawczych zaburzeń w przyswajaniu polskiego systemu gramatycznego w warunkach interferencji języka szwedzkiego, jak i mechanizmów rządzących przyswajaniem/rozpadem polskiego systemu językowego w tym otoczeniu językowym (ibid.: 131).

Dzieląc $\mathrm{z}$ autorem przekonanie o możliwości wydobycia $\mathrm{z}$ takiej analizy mechanizmów decydujących o przyswajaniu systemu językowego polszczyzny, chcę pokazać za nim, jakie tendencje rządzą nabywaniem języka etnicznego przez dzieci polonijne. 
Podejmując swoją analizę, Laskowski opisuje system fonologiczny, fleksję, składnię i słownictwo nabywane przez dzieci, czyli kilka elementów tego systemu. W ramach przeprowadzonej analizy fleksyjnej autor opisuje przyswojenie rodzaju gramatycznego, kategorii liczby i przypadka, kategorii określoności, zaimków zwrotnych i dzierżawczo-zwrotnych, aspektu i czasów czasownika oraz jego kategorii osoby. Analiza przyswajania kategorii przypadka zostaje uszczegółowiona w części trzeciej monografii (ibid.: 133-222).

Przedstawiając przyswajanie systemu fonologicznego przez polskie dzieci w Szwecji, autor zwraca uwagę na zaburzenia w tym procesie, szczególnie w podsystemie spółgłosek szczelinowych i zwarto-szczelinowych. W rezultacie zderzenia bogatego podsystemu polskiego, złożonego $\mathrm{z}$ dwunastu fonemów, z ubogim podsystemem szwedzkim, liczącym tylko trzy bezdźwięczne spiranty, często występują opóźnienia w opanowaniu podsystemu polskiego. I tak na przykład dziewięcioletnie dziecko polonijne ma w swoim systemie tylko cztery spółgłoski szczelinowe /s/, /z/, /śl, /źl, z czego wynika, że brak w nim afrykat i spółgłosek dzią̧łowych, jest natomiast opozycja dźwięczności.

Analizując ogólnie zjawiska fleksyjne, Laskowski zwraca uwagę na wyrównywanie morfonologiczne tematu fleksyjnego zarówno w odmianie imion (np. w lasie 'w lesie'), jak i czasowników (np. możem 'mogę'). Dość częste są również błędy w wyborze końcówek fleksyjnych.

Mimo że oba języki mają kategorię rodzaju, to jednak jej struktura jest odmienna w każdym z nich. Trzem polskim rodzajom w liczbie pojedynczej (męskiemu, żeńskiemu i nijakiemu) odpowiadają w języku szwedzkim dwa: utrum (rzeczowniki żywotne i część nieżywotnych) i neutrum (rzeczowniki nieżywotne i kilka żywotnych). Kryterium rozróżniania rodzajów jest łączliwość z rodzajnikiem, którego brak w polszczyźnie. Wpływ systemu szwedzkiego powoduje rozchwianie tej kategorii w idiolektach dzieci polonijnych. Szczególnie rozchwiana jest ona w liczbie mnogiej, gdzie można obserwować częściowe tylko opanowanie opozycji rodzaju męskoosobowego i niemęskoosobowego.

Kategoria liczby ma podobną strukturę w obu językach, jednakże nie obejmuje ona szwedzkiego czasownika, co prowadzi do częstych błędów typu chłopczyki chce, $\dot{z}$ eby ten pan pomogli 'chłopczyki chcą, żeby ten pan pomógł'.

Ponieważ kategoria przypadka nie występuje w języku szwedzkim, jej używanie $\mathrm{w}$ idiolektach dzieci polonijnych ulega rozchwianiu, jednak kolejność przyswajania przypadków lub ich utraty jest zgodna ze strukturą polskiego systemu przypadkowego. Autor odróżnia przypadki mocne, bardziej stabilne w systemie (M, B, D), i przypadki słabe, trudniej przyswajane przez dzieci i dlatego mniej stabilne (C, Msc., N). Laskowski podkreśla, że najbardziej nacechowany przypadek, jakim jest celownik, jest też najmniej stabilny w idiolektach dzieci polonijnych, np. ktoś pomaga jego 'ktoś pomaga jemu; ktoś mu pomaga', nic się jego nie stało 'nic się jemu nie stało; nic mu się nie stało'. 
Laskowski zwraca uwagę na trzy czynniki ogólne mające wpływ na użycie przypadków w idiolektach dzieci polonijnych:

1. niepolskie nazwy własne, zarówno osobowe, jak i geograficzne, są zwykle nieodmieniane;

2. lepiej przyswajana jest odmiana zaimków, zwłaszcza osobowych, niż rzeczowników;

3. nawet jeśli biernik i dopełniacz są słabo opanowane przez dzieci, lepiej są opanowane w kontekstach z przyimkiem niż w kontekstach bezprzyimkowych.

Kategoria określoności, której brak w polszczyźnie, występuje w języku szwedzkim, co prowadzi w wyniku interferencji do jej ekspansji w idiolektach dzieci (a w rezultacie do nadużywania zaimka ten).

Kategoria aspektu czasowników, obca językowi szwedzkiemu, ulega w idiolektach dzieci polonijnych rozchwianiu, co można sprowadzić do zastępowania czasowników dokonanych niedokonanymi. W analizowanych wypowiedziach dzieci polonijnych widoczne jest także przejmowanie szwedzkiego następstwa czasów, czyli reguły, która wymaga w zdaniach złożonych podporządkowania czasu czasownika w zdaniu podrzędnym czasowi orzeczenia w zdaniu nadrzędnym.

$\mathrm{W}$ języku szwedzkim kategoria osoby jest wyrażana analitycznie przez zaimek osobowy, co w wyniku interferencji prowadzi do nadużywania zaimków osobowych przez dzieci polonijne.

Składnia w języku szwedzkim także wpływa na składnię wypowiedzi dzieci polonijnych, co wyraża się $\mathrm{w}$ tendencji do stosowania $\mathrm{w}$ ich polszczyźnie reguł szyku znanych $\mathrm{z}$ języka szwedzkiego, do unikania podwójnego przeczenia, a także do stosowania nieodmiennego zaimka względnego co, odpowiadającego szwedzkiemu zaimkowi som. Osobno Laskowski omawia kalki syntaktyczne z języka szwedzkiego pojawiające się w polszczyźnie dzieci polonijnych.

Charakteryzując słownictwo dzieci, Laskowski zwraca uwagę na ubóstwo ich zasobu leksykalnego, dość często ograniczonego do sfery życia rodzinnego i zjawisk z nim związanych. Podkreśla także różnice ilościowe w polskim zasobie słownym poszczególnych dzieci. Brak słów polskich nazywających zjawiska, o których chcą mówić dzieci, powoduje adaptację morfologiczną szwedzkich wyrazów (np. kompis 'kolega, przyjaciel'; dator 'komputer') bądź też używanie oryginalnych wyrazów szwedzkich na zasadzie świadomego wtrętu językowego. Dalej autor analizuje strategie substytucji leksykalnej, strategie zapożyczania wyrazów, kalki leksykalne oraz metatekstowe sygnały niepewności co do poprawności używanego słowa, np. Na szwedzkim to...rozmawialiśmy o...jak to się nazywa ordklass 'części mowy' (ibid.: 126).

Trzecia część monografii Laskowskiego zawiera szczegółowe rozważania na temat akwizycji kategorii przypadka w polszczyźnie dwujęzycznych dzieci polonijnych. Autor najpierw omawia stan badań nad nabywaniem przypadka przez mieszkające w Szwecji dzieci używające innych języków słowiańskich. Potem przechodzi 
do opisu 14 idiosystemów przypadkowych, zaobserwowanych w całej badanej populacji dzieci polonijnych, po czym stwierdza, że

[...] stopień opanowania kategorii przypadka (a właściwie poziom znajomości języka polskiego) nie pozostaje w żadnym związku $\mathrm{z}$ wiekiem dziecka: $\mathrm{z}$ jednej więc strony bezprzypadkowy idiolekt to przykład zupełnego braku kategorii przypadka u dziesięcioletniego dziecka, z drugiej zaś wśród dzieci posługujących się w pełni rozbudowaną ową kategorią gramatyczną [...] znajdują się pięcio- i sześciolatkowie (ibid.: 139).

Dalej uczony zauważa, że w materiale językowym widoczne są trzy przypadki, trudniej nabywane przez dzieci, tzn. celownik, miejscownik i narzędnik, które nazywa przypadkami słabymi. Przeciwstawia je trzem przypadkom mocnym, czyli mianownikowi, przypadkowi niezależnemu, oraz dwom przypadkom zależnym - biernikowi i dopełniaczowi. Podsumowując te rozważania, stwierdza, że wszystkie sposoby nabywania lub tracenia przypadka przez dwujęzyczne dziecko polonijne w Szwecji można sprowadzić do jednego modelu, złożonego z sześciu przypadków (wołacz nie był uwzględniany w badaniach):

$$
\mathrm{M} \rightarrow \mathrm{D} \rightarrow \mathrm{B} \rightarrow \mathrm{N} \rightarrow \mathrm{M} \rightarrow \mathrm{C}
$$

Kolejność opanowywania przypadków zgodna jest w nim z kierunkiem strzałki, a ich tracenie zaczyna się kolejno od końca w kierunku przeciwnym do kierunku strzałki.

W dalszej części rozważań na temat nabywania poszczególnych przypadków uczony podkreśla, że proces ten jest złożony, co oznacza, że dziecko nie opanowuje pojedynczych przypadków w przedstawionej kolejności, a po opanowaniu przypadka $x$, mocniejszego od przypadka y, przechodzi do opanowania następnego. W rzeczywistości każdy przypadek przyswajany jest stopniowo, co polega na opanowywaniu poszczególnych funkcji danego przypadka wraz z wyrażającą je formą, np. dopełniacz cząstkowy, genetivus partitivus, jest przyswajany przed dopełniaczem po przeczeniu.

W rezultacie - stwierdza autor - procesy przyswajania poszczególnych przypadków częściowo nakładają się na siebie, dając skomplikowany, wielowątkowy przebieg tego procesu jako całości (ibid.: 123).

W partii szczegółowej trzeciej części monografii Laskowski analizuje zaburzone przyswajanie biernika na tle rozpadu kategorii przypadka, bardzo ograniczone używanie celownika jako "przypadka zbędnego", używanie miejscownika jako „przypadka fakultatywnego", stosowanie narzędnika jako „przypadka opornego”, wreszcie przyswajanie przez dzieci polonijne sześciu funkcji dopełniacza: dopełniacza adwerbalnego, po przyimku, po liczebniku, w funkcji wyrażania czasu (temporalnej), po negacji i w grupach nominalnych po innym rzeczowniku. 
Już na początku omawiania monografii Laskowskiego zwróciłem uwagę na jego świadomość tego, że analizuje zbiór różniących się znacznie idiolektów pojedynczych rozmówców, a nie jeden system językowy reprezentowany przez różne idiolekty. Mogłoby to sugerować powiązanie analizowanych idiolektów z osobami rozmówców: ich biografiami językowymi, intensywnością kontaktów z każdym z języków i stopniem ich opanowania, z czym zwykle mamy do czynienia w pracach na temat bilingwizmu dzieci i młodzieży. Jednak w przeważającej części jego monografii znajdujemy albo opinie na temat całej zbiorowości dzieci polonijnych w Szwecji (tak w części pierwszej pracy), albo przykłady realizacji konkretnych struktur językowych przez pojedyncze dzieci, o których dowiadujemy się w istocie niewiele: czasami poznajemy ich wiek i płeć, częściej dowiadujemy się, jaki typ realizacji danej struktury reprezentują (w pozostałych częściach książki). W monografii mamy zatem fragmenty pojedynczych idiolektów, ale nie mamy choćby zwięźle zarysowanych sylwetek tych dzieci jako osób bilingwalnych. Poza jednym wyjątkiem: studium przypadku dwuletniej dziewczynki D, do której rodzice zwracali się konsekwentnie w dwu językach: po polsku (ojciec) i rosyjsku (matka), stosując tak zwaną strategię osoby, dość często pojawiającą się w wychowywaniu dzieci dwujęzycznych. Obserwacje zachowań językowych autor prowadził między 17. a 23. miesiącem życia dziecka, a więc w fazie holofraz. Podsumowanie analizy danych $\mathrm{z}$ obserwacji stanowią uwagi na temat uwarunkowań semantyczno-pragmatycznych nabywania przypadków i ich funkcji, które warto w tym miejscu przy toczyć:
Uderzający jest porządek, w jakim przyswajane są pierwsze formy i funkcje przy- padka, a przede wszystkim wyraźnie semantyczna (a właściwie semantyczno-prag- matyczna, zawsze uwarunkowana sytuacyjnie) motywacja tych ontogenetycznie wczesnych bytów językowych. Ważne znaczenie z punktu widzenia badań nad przy- swajaniem języka przez dziecko, ale też ze względu na teorię przypadka, ma fakt, że pierwsze motywowane semantycznie protoprzypadki (dopełniacz posiadacza, celow- nik adresata i nieco później - genetivus partitivus) pojawiają się w mowie tego dziec- ka już w fazie holofraz. Stosunkowo późno, w fazie wypowiedzi dwuwyrazowych, do repertuaru używanych przez nie przypadków dołączony zostaje biernik dopeł- nienia bliższego. Jednak nawet to pierwsze użycie biernika winno się interpretować jako motywowane semantycznie: repertuar przypadków zostaje wzbogacony o formę oznaczającą patiensa czynności (ibid.: 220).

Jak zatem widać, dane uzyskane dzięki obserwacji dwuletniego dziecka potwierdzają ogólne wnioski, do których autor doszedł w wyniku analizy całego materiału zebranego od dzieci w różnym wieku. Co więcej, pochodzący od dwuletniego dziecka materiał pokazuje początki tworzenia się w jego umyśle semantyczno-pragmatycznych funkcji przypadka bardzo wcześnie, bo już w fazie holofraz. Wartość uzyskanych wniosków potwierdza prowadzona konsekwentnie przez Laskowskiego analiza porównawcza procesu nabywania przypadków przez polskie dzieci dwuję- 
zyczne z wnioskami odnoszącymi się do nabywania przypadków przez dwujęzyczne dzieci słowiańskie, mówiące po serbsku i chorwacku, a także z wnioskami na temat nabywania przypadków przez jednojęzyczne polskie dzieci podanymi w pracach Magdaleny Smoczyńskiej (1985) i Edwarda Łuczyńskiego (2004).

Równocześnie jednak Laskowski zwraca uwagę na różnice między zachowaniami językowymi dziecka $\mathrm{D}$, a ogólnym obrazem rozwoju mowy znanym z literatury przedmiotu. Tłumaczy to faktem, że „przebieg procesu przyswajania języka może być i jest w szczegółach różny u różnych dzieci” (ibid.: 221). Specyfikę tego procesu u dziecka D wyjaśnia możliwością obserwowania różnic między znaczeniem a sposobami jego wyrażania związanych z tym, że niezmienności znaczenia towarzyszyła zmienność formy przekazywanych w obu językach informacji. Swe obserwacje wiąże z uwagami na temat kognitywnych konsekwencji bilingwizmu, przedstawionymi w pracy badaczy szwajcarskich (zob. Hamers, Blanc 1990).

O części trzeciej książki trzeba powiedzieć, że stanowi ona model badania jednej kategorii fleksyjnej języka polskiego nabywanej w warunkach bilingwizmu - kategorii przypadka, „najbardziej skomplikowanej kategorii gramatycznej języka polskiego" (ibid.: 225). W zakończeniu książki autor podkreślił destrukcyjną rolę języka interferującego w opanowaniu tej kategorii, dodając jednak, że

[...] nawet w wypadku defektywnego przyswajania tej kategorii [...] uruchamiane są mechanizmy "terapeutyczne" zdeterminowane przez funkcjonalną strukturę danej kategorii gramatycznej [...]. W wypadku kategorii przypadka jest to przede wszystkim mechanizm substytucji przypadków „słabych” (silniej funkcjonalnie nacechowanych) przez przypadki „mocne” (mniej funkcjonalnie nacechowane), także zastępowanie przypadka „słabego" przez rodzime frazy przyimkowe (np. dla + dopełniacz w miejsce celownika). W tej ostatniej sytuacji [...] mówiący może uciekać się do kalk językowych, sięgając po semantycznie adekwatną szwedzką konstrukcję syntaktyczną (typ syn do Bogdana 'syn Bogdana', fotografia na Maciusia). [...] Są to $\mathrm{w}$ istocie te same mechanizmy językowe (i kognitywne), które można zaobserwować, śledząc procesy przyswajania języka przez polskie dzieci monolingwalne (ibid.: 225).

Pragnieniem autora było, by jego praca stanowiła przyczynek do teorii przyswajania języka w środowisku bilingwalnym, co niewątpliwie udało mu się zrealizować, gdyż omawiana praca stanowi wręcz wzór takiej trzyfazowej analizy: socjolingwistycznej, czyli funkcjonowania dwu języków używanych przez badaną grupę, ogólnej analizy strukturalnej używania jednego języka (tu: etnicznego), wreszcie szczegółowej - procesu przyswajania jednej kategorii gramatycznej języka etnicznego.

Podejmując badania języka dzieci polonijnych w Szwecji, Laskowski miał świadomość ich znaczenia:

Jest to jedyne jak dotąd opracowanie poświęcone językowi drugiego pokolenia polskich emigrantów, oparte na systematycznych, szeroko zakrojonych badaniach dużego zbioru dzieci i młodzieży polonijnej (ibid.: 10). 
Podkreślał przy tym, że głównym ich celem nie jest socjolingwistyczna charakterystyka szwedzkiej Polonii, nawet tylko jej drugiej generacji, lecz dotarcie do mechanizmów lingwistycznych wpływających na przyswajanie przez dziecko języka w warunkach dwujęzyczności. Uważał bowiem, że sama sytuacja bilingwizmu „wymusza intuicyjną »świadomość różnicy między językiem i systemem pojęciowym, wyrażanym inaczej w każdym z przyswajanych języków” (ibid.: 18). Tak określony cel badań wynikał ze świadomości, że w istniejących opracowaniach stosunkowo często analizuje się socjo- i psycholingwistyczne problemy przyswajania języka przez dzieci dwujęzyczne, a o wiele mniej uwagi poświęca się skomplikowanemu oddziaływaniu dwu różnych systemów językowych na proces przyswajania języka etnicznego. Pisząc to, miał niewątpliwie rację. Tu warto dodać, że stwierdzenie to odnosi się w równym stopniu do badań prowadzonych na świecie, co do badań podejmowanych w Polsce. Sytuacja taka jest z jednej strony rezultatem rozwoju badań socjolingwistycznych i psycholingwistycznych w Polsce, co wiązało się odejściem od badań strukturalistycznych, odnoszących się do systemów językowych. $Z$ drugiej strony trzeba zauważyć, że czołowi polscy strukturaliści przez lata nie wyrażali zainteresowania badaniem polszczyzny poza Polską, traktując ten obszar w zasadzie jako peryferie badań lingwistycznych. Podejmując badania akwizycji języka polskiego przez dwujęzyczne dzieci polskie ze Szwecji, Laskowski przełamał oba ograniczenia w badaniach lingwistycznych w Polsce. Więcej nawet, jego badania i monografia na temat akwizycji polszczyzny w warunkach dwujęzyczności nadały badaniom języka polskiego dzieci i młodzieży i badaniom nad bilingwizmem polsko-obcym odpowiednią rangę naukową i prestiż.

Badania procesu akwizycji języka w sytuacji bilingwizmu muszą być żmudne i trudne $\mathrm{z}$ kilku powodów. Pierwszym $\mathrm{z}$ nich jest fakt, że badany proces jest rozciągnięty w czasie, badania muszą więc trwać kilka lat (na pewno więcej niż rok). Drugim - konieczność dokonywania regularnych badań (np. co miesiąc) każdej osoby. Kolejnym jest objęcie badaniami grupy jednorodnej językowo, gdyż z góry należy zakładać, że proces ten przebiega inaczej u osób znających języki o różnych strukturach: jakiś język słowiański, jeden z języków europejskich lub jeden z języków o strukturze odmiennej od języków słowiańskich i europejskich. Jeszcze innym powodem trudności jest konieczność znajomości przez badacza języka ojczystego badanych, wpływającego na proces nabywania polszczyzny. Ostatnim, ale nie najmniej ważnym jest konieczność bardzo dobrej znajomości struktury obu języków, wchodzących w kontakt. Laskowski spełniał prawie wszystkie te warunki, niektóre nawet $\mathrm{z}$ nawiązką. Za "nawiązkę” uważam jego ogromne doświadczenie badawcze w zakresie analizy struktury morfologicznej języka polskiego na tle innych języków słowiańskich, które bardzo się przydało. Ujawnił swoją nową kompetencję w zakresie badań bilingwizmu jako zjawiska językowego i społecznego. Równocześnie jednak w swej ostatniej monografii pokazał „[...] nie po raz pierwszy, że do jego podstawowych zainteresowań językoznawczych należała morfologia i jej aparat pojęciowy", na co zwrócił uwagę Maciej Grochowski (2014: 14). 
Z zakończenia książki widać, że Laskowski miał świadomość, iż opisywany „język w zagrożeniu" jest ważnym i aktualnym problemem społecznym:

Niezależnie od kraju osiedlenia rodziców ich dzieci stają przed tymi samymi problemami: dostosowanie się do życia w dwu różnych otoczeniach kulturowych, konieczność nauczenia się życia w dwu różnych językach. Problem ten dotyczy już teraz co najmniej dziesiątek tysięcy polskich dzieci, a będzie w najbliższych latach narastał niemal lawinowo. Mówi się o blisko dwu milionach Polaków, głównie ludzi młodych, którzy w ciągu ostatnich lat znaleźli zatrudnienie w krajach Unii Europejskiej [...]. Ilu rodziców powróci do kraju, ilu zaś zdecyduje się na pozostanie w Irlandii, Francji czy w Niemczech? Dziesiątki tysięcy dzisiejszych „eurosierot” staną się zapewne niebawem częścią polskiej diaspory. Tym dzieciom i ich rodzicom trzeba stworzyć warunki sprzyjające zachowaniu języka polskiego, zachęcić do podtrzymywania związków z ojczyzną i kulturą (2009: 226).

Pisząc te słowa, uczony nie tylko sygnalizował ów problem, ale też apelował o stworzenie dzieciom i ich rodzicom warunków do zachowania polszczyzny w drugim pokoleniu i w pokoleniach następnych. Apelował o odpowiednią akcję edukacyjną wśród młodzieży, co naturalne, ale także wśród rodziców, podkreślając, jak wielki mają wpływ na zachowanie języka etnicznego. Podjął również działania mające na celu stworzenie przy Polskiej Akademii Umiejętności w Krakowie grupy specjalistów zajmujących się problemami społecznymi, psychicznymi, kulturowymi i językowymi młodzieży polonijnej, grupy rozumianej przez niego jako zorganizowane lobby na rzecz podjęcia działań zmierzających do zachowania polszczyzny w kręgu migrantów europejskich i ich dzieci. Jako lider tej grupy był autorem pism kierowanych do władz odpowiednich resortów i Stowarzyszenia „Wspólnota Polska”, postulujących konkretne działania. Mimo postępującej choroby brał udział w konferencjach krajowych i zagranicznych, gdzie przedstawicielom Polonii zwracał uwagę na znaczenie zachowania języka polskiego wśród młodzieży. W lutym 2014 r. należał do działaczy polonijnych i językoznawców, którzy powołali w Szkocji, w Edynburgu, Stowarzyszenie Promocji Języka Polskiego za Granicą (Association for the Promotion of Polish Language Abroad - APPLA). W lipcu 2014 r. przy współudziale międzynarodowej organizacji Bilingualism Matters Stowarzyszenie to rozpoczęło kampanię na rzecz dwujęzyczności pod hasłem Podaruj dziecku swój język ojczysty.

O tej działalności Laskowskiego piszę, gdyż miałem możność uczestniczenia w niej i obserwowania starań uczonego, który miał świadomość, że od postawionej w monografii diagnozy trzeba przejść do działania, że bezzwłocznie trzeba podjąć działania edukacyjne w kręgu młodzieży polonijnej i jej rodziców. O tym, jak taka akcja jest ważna, wie każdy, kto zdaje sobie sprawę, że tylko 30\% młodzieży polskiej i polonijnej, przebywającej obecnie w Wielkiej Brytanii, uczestniczy w nauczaniu prowadzonym przez polskie szkoły sobotnie. Ale ta informacja oznacza również, że aż 70\% tej młodzieży nie chodzi do polskich szkół. Nie chodzi, ponieważ jej rodzi- 
ce - małżeństwa polskie lub mieszane - uznali, że trzeba skoncentrować się raczej na dobrym opanowaniu angielszczyzny, od czego zależy sukces przyszłej edukacji i kariery zawodowej w tym kraju. Zdaniem tych rodziców polszczyznę, nawet przywiezioną niedawno i znaną dobrze z Polski, można zatem skazać na zapomnienie jako język mniej ważny czy wręcz nieważny w przyszłym życiu w Unii Europejskiej. Rodzice myślą tak i podejmują takie decyzje, ponieważ nie znają zupełnie europejskiej polityki edukacyjnej, zalecającej wielojęzyczność, rozpoczynającą się od dwujęzyczności i różnojęzyczności (zob. Szul 2003; Gębal 2013: 40-59). To dlatego tak ważna jest akcja uświadamiająca rodziców o dwujęzyczności jako wartości, niezbędnej do korzystania ze wszystkich możliwości, jakie stwarza Unia (zob. Laskowski 2013).

$\mathrm{W}$ ostatnich dniach $2014 \mathrm{r}$. ukazało się w wydawnictwie Petera Langa angielskie tłumaczenie monografii Laskowskiego pod tytułem Language Maintenance - Language Attrition. The Case of Polish Children in Sweden. Do ostatnich chwil życia uczony pracował nad tekstem tego wydania, przygotowując uzupełnienia i poprawki. Informuje o nich Anna Czelakowska, która książkę zredagowała i poprzedziła notą edytorską. Ważną nowością, szczególnie z punktu widzenia niepolskiego odbiorcy, jest wprowadzenie do części pierwszej nowego, 8-stronicowego rozdziału The Polish diaspora in a multicultural Europe (Diaspora polska w wielokulturowej Europie). Przedstawiwszy zwięźle historię emigracji z ziem polskich, autor koncentruje się w nim na migracjach najnowszych z przełomu XX i XXI w., pokazując imigrantów z Polski na tle imigrantów z innych krajów słowiańskich. I tak w okresie przedakcesyjnym $w$ tak zwanych starych krajach UE przebywało 3800 tys. imigrantów z krajów słowiańskich, z czego największą grupę stanowili imigranci z Polski. Liczyła ona w tym okresie 1297647 osób, w większości (64,7\%) ludzi młodych, bo w wieku od 15 do 34 lat (Laskowski 2014: 22). W dalszej części tego rozdziału została przedstawiona liczebność polskiej diaspory w krajach UE oraz w USA i Kanadzie. $\mathrm{Z}$ załączonej tabeli dowiadujemy się, że na przykład w Wielkiej Brytanii grupa migrantów polskich liczy 950 tys. osób, w tym większość (81\%) osób młodych w wieku od 18 do 34 lat (ibid.: 24 ).

Wprowadzone $\mathrm{w}$ wydaniu angielskojęzycznym zmiany obejmują modyfikacje komentarzy opisywanych zjawisk językowych, uwzględnienie najnowszej literatury odnoszącej się do zjawiska bilingwizmu, opublikowanej za granicą i w Polsce, w tym trzech artykułów autorstwa Laskowskiego, m.in. jego ważnego tekstu Język a tożsamość etniczna. Kształtowanie się poczucia narodowego młodej polskiej diaspory w warunkach wielokulturowości (2013) oraz zmianę zakończenia części trzeciej, w którym autor podkreśla rolę czynników semantycznych decydujących o przyswojeniu przypadków (2014: 225-228). Przeciwstawia się w ten sposób poglądom o roli czynników syntaktycznych w akwizycji przypadków, przeważających w dotychczasowej literaturze naukowej. Uczony pracował także nad nowym rozdziałem, poświęconym kognitywnym konsekwencjom wczesnego bilingwizmu, między innymi jego pozytywnemu wpływowi na rozwój języka dziecka i kształtowanie się jego tożsamo- 
ści. Niestety, rozdział ten nie został ukończony i ostatecznie nie znalazł się w angielskiej wersji pracy.

Publikację książki Language Maintenance - Language Attrition. The Case of Polish Children in Sweden Laskowskiego trzeba uznać za ważne wydarzenie naukowe z tego względu, że dzieci migrantów polskich stają się w wielu krajach europejskich grupą (bardzo) liczną i zwracającą uwagę nie tylko nauczycieli, ale także specjalistów w zakresie edukacji z różnych krajów UE. Świadczą o tym zagraniczne prace na temat adaptacji językowej i kulturowej dzieci polskich, których część została uwzględniona w monografii Laskowskiego. W tej sytuacji angielskojęzyczne wydanie monografii stanowi niezwykle potrzebny i istotny głos lingwistyki polskiej na temat tego aktualnego problemu językowego, kulturowego i edukacyjnego. Głos, który z pewnością zostanie uwzględniony w późniejszych publikacjach na ten temat i w podejmowanych działaniach edukacyjnych.

\section{Literatura}

Dubisz S. (red.), 1997a, Język polski poza granicami kraju, „Najnowsze Dzieje Polszczyzny”, Opole.

Dubisz S., 1997b, Język polski poza granicami kraju - Wstępne informacje i definicje; [w:] Dubisz 1997a, s. 13-46.

Dubisz S., 1997c, Język polski poza granicami kraju - Próba charakterystyki kontrastowej, [w:] Dubisz 1997a, s. 324-376.

GęBal P.E., 2013, Modele kształcenia nauczycieli języków obcych w Polsce i w Niemczech. W stronę glottodydaktyki porównawczej, „Biblioteka «LingVariów». Glottodydaktyka” t. 6, Kraków.

Grochowski M., 2014, Pożegnanie Profesora Romana Laskowskiego, „LingVaria” nr 2 (18), s. 7-16. DOI: 10.12797/LV.09.2014.18.01

Hamers J.F., BlanC M.H., 1990, Bilinguality and Bilingualism, Cambridge.

LAsкowski R., 1984, Nad polszczyzna w Kazachstanie (logika zmian językowych), [w:] J. Rieger, W. Werenicz (red.), Studia nad polszczyzną kresowa III, Wrocław, s. 23-31.

LASKowsкi R., 1991, Społeczne uwarunkowania zachowania języka polskiego przez drugie pokolenie polskich imigrantów w Szwecji (Uwagi wstępne), [w:] S. Gajda (red.), Wariancja w języku. III Opolskie Spotkania Językoznawcze. Szczedrzyk 10/11.10.1989, Opole, s. 103-108.

Laskowski R., 2009, Język w zagrożeniu. Przyswajanie języka polskiego w warunkach polsko-szwedzkiego bilingwizmu, Kraków.

LAsKowski R., 2013, Język a tożsamość etniczna. Kształtowanie się poczucia narodowego młodej polskiej diaspory w warunkach wielokulturowości, „LingVaria” nr 2 (16), s. 77-91. DOI: 10.12797/LV.08.2013.16.05

Laskowski R., 2014, Language Maintenance - Language Attrition. The Case of Polish Children in Sweden, tłum. Ł. Wiraszka, red. A. Czelakowska, „Warschauer Studien zur Germanistik und zur Angewandten Linguistik" Bd 20, Frankfurt am Main - New York - Oxford - Wien. 
Later-ChodyŁowa E., 1992, Polonia w krajach skandynawskich: Dania, Finlandia, Norwegia, Szwecja, [w:] B. Szydłowska-Ceglowa 1992a, s. 571-627.

LIGARA B., 1987, Galicyzmy leksykalne w listach Zygmunta Krasińskiego na tle wpływów francuskich w polszczyźnie XIX wieku. Studium bilingwizmu polsko-francuskiego, Kraków.

ŁUCZYŃsKi E., 2004, Kategoria przypadka w ontogenezie języka polskiego czyli o wchodzeniu dziecka w rzeczywistość gramatyczną, Gdańsk.

Miodunka W.T., 2003, Bilingwizm polsko-portugalski w Brazylii. W stronę lingwistyki humanistycznej, Kraków.

Miodunka W.T., 2010, Dwujęzyczność, walencja kulturowa i tożsamość (e)migracji polskiej w świecie, „Biuletyn Polskiego Towarzystwa Językoznawczego” LXVI, s. 51-71.

Sękowska E., 1997, Polszczyzna Polonii w Szwecji, [w:] S. Dubisz 1997a, s. 196-202.

SĘKOwsKa E., 2010, Język emigracji polskiej w świecie. Bilans i perspektywy badawcze, Kraków.

Smoczyńska M., 1985, The acquisition of Polish, [w:] D.J. Slobin (red.), The Crosslinguistic Study of Language Acquisition, Vol. I, The data, Hillsdale - New Jersey, s. 595-686.

Szul R., 2003, Europa językowa, „Języki Obce w Szkole” nr 6, s. 7-24.

SzydŁowska-Ceglowa B. (red.), 1992a, Polonia w Europie, Poznań.

SzydŁowska-Ceglowa B., 1992b, Przemiany języka polskiego na emigracji. Mechanizmy i tendencje, [w:] B. Szydłowska-Ceglowa 1992 a, s. 177-208.

Uggla N. A., 1991, Polacy w Szwecji. Zarys historyczny, „Studia Scandoslavica” 13, s. 63-101.

\section{The importance of Roman Laskowski's works for the study of acquisition of Polish outside of Poland, and of Polish-foreign bilingualism \\ Summary}

The paper discusses those of Roman Laskowski's works which touch upon the acquisition of Polish as an ethnic language, by Polish children in Sweden. These children are bilingual because they speak both Polish and Swedish. In his 2009 monography, Laskowski first presents their Polish-Swedish bilingualism, then gives a general description of their Polish, and finally focuses on an analysis of the process of acquisition of grammatical cases as a central category of Polish. The importance of Laskowski's publications is defined by the fact that they are, so far, only such works about the acquisition of Polish outside of Poland. Laskowski is to be counted among the pioneers of research into Polish-foreign bilingualism. 